ОГЛЯД ТРАДИЦІЙНИХ ТА СУЧАСНИХ МЕТОДІВ І ПІДХОДІВ ДЛЯ ФОРМУВАННЯ МІЖКУЛЬТУРНОЇ КОМПЕТЕНТНОСТІ КУРСАНТІВ ВИЩИХ ВІЙСЬКОВИХ НАВЧАЛЬНИХ ЗАКЛАДІВ

\title{
OVERVIEW OF TRADITIONAL AND CURRENT METHODS AND APPROACHES FOR THE FORMATION OF INTERCULTURAL COMPETENCE OF CADETS OF HIGHER MILITARY EDUCATIONAL INSTITUTIONS
}

У статті розглянуто основні рівні методології наукових досліджень, що варіюються від фрілософрського до конкретно-наукового, ma їх вплив на вибір стратегії навчання викладачем під час іншомовної підготовки курсантів вищих військових навчальних закладів. З'ясовано сутність поняття «методологія» та варіації іï трактування науковцями, а також диференціацію із поняттям «методика». Зазначено роль гуманітарної складової частини загалом та іноземної мови зокрема у розвитку професійних компетентностей військових фрахівців. Підкреслено важливість викладання гуманітарних дисциплін на належному рівні для підготовки квалісрікованих військових кадрів Збройних сил України, зважаючи на сучасні інтеграційні процеси до європейського освітнього простору та стандартів НАTO та значення формування міжкультурної компетентності для професійного становлення військового фрахівця. Проаналізовано характерні риси традичійних та сучасних методів та підходів, які застосовуються під час викладання іноземних мов, а саме: натуральний підхід, граматично-перекладний та текстуально-перекладний методи, прямий метод вивчення іноземних мов, аудіолінгвальний та аудіовізуальний підходи, усний підхід або ситуативне вивчення, комунікативний підхід, метод мовчання, метод занурення, метод повного фрізичного реагування, метод «громади» або ж метод «радника». Зазначено важливість уміння викладача правильно й виправдано добирати методи та підходи, враховуючи поставлені чілі навчання та очікувані програмні результати, вдаючись до ідей еклектичного підходу. Здійснено спробу хронологічного огляду науково-педагогічних підходів та методів, що застосовуються під час іншомовної підготовки, з метою простежити динаміку розвитку методології викладання іноземних мов. З'ясовано особливості методів та підходів, їх походження, а також переваги, недоліки та перспективи застосування у системі вищої військової освіти під час іншомовної підготовки.

Ключові слова: міжкультурна компетент ність, військова освіта, методи навчання, педагогічні підходи, іноземні мови.
The article considers the main levels of research methodology, ranging from philosophical to specific scientific and their impact on the choice of teaching strategy by the teacher during the foreign language training of cadets of higher military educational institutions. The meaning of the concept of "methodology" and variations of its interpretation by scientists as well as differentiation with the concept of "methods" are clarified. The role of the humanitarian component in general and the foreign language in particular in the development of professional competencies of military specialists is noted. The importance of teaching the humanities at the appropriate level for the training of qualified military personnel of the Armed Forces of Ukraine was emphasized as being a result of current integration processes into the European educational environment and NATO standards and the significance of intercultural competence for professional development was highlighted. The peculiarities of traditional and modern methods and approaches used in teaching foreign languages are analyzed, namely: the natural approach, the grammartranslation and text-translation methods, the direct method of learning foreign languages, the audiolingual and audiovisual approaches, the oral-situational approach, the communicative approach, the silent way method, the suggestopedia learning, the method of total physical response, and community language learning. The importance of the teacher's ability to correctly and reasonably choose methods and approaches, taking into account the goals of training and expected programme results, applying the concepts of an eclectic approach. An attempt is made to chronologically review the scientific and pedagogical approaches and methods used during foreign language training, in order to trace the dynamics of the methodology of teaching foreign languages. The peculiarities of methods and approaches, their origin, as well as the advantages, disadvantages and prospects of application in the system of higher military education during foreign language training are clarified.

Key words: intercultural competence, military education, teaching methods, pedagogical approaches, foreign languages.
Постановка проблеми у загальному вигляді та її зв'язок із важливими науковими чи практичними завданнями. Зміст сучасної військової освіти постійно оновлюється застосуванням нових науково-педагогічних підходів, а також переосмисленням або інтерпретацією давно відомих. Сучасні вимоги до знання іноземних мов роблять актуальними нововведення у методиці їх викла- дання. Система вдало підібраних педагогічних підходів дозволяє сорормувати у курсантів систему ключових та предметних компетентностей, що $є$ основою фрормування особистісних та професійних якостей майбутнього військовослужбовця. Вивчаючи наукові явища та їх закономірності, науковець звертається до відбору методологічних підходів для системного і всебічного вивчення про- 
блеми. Досить тривалий час тривало дослідження і розрізнення понять «методологія» та «методика» через їх початкове ототожнення. Над таким питанням розмірковували В. Афранасьєв, Ч. Барнард, О. Бережна, І. Блауберг, В. Бондар, М. Каган, В. Краєвський, В. Маслов, О. Новіков, Ф. Перегудов, В. Садовський, Ф. Тарасенко, Г. Щедровицький, Е. Юдін та інші. Для викладача іноземної мови досі залишається актуальною проблема аналізу і систематизації методологічної та методичної бази для вибору оптимальних та універсальних методів та підходів у викладанні іноземної мови, зокрема англійської, для фрормування ключових та професійних компетентностей курсантів вищих військових навчальних закладів.

Аналіз останніх досліджень і публікацій. Методологія наукового дослідження для науковця $€$ тим засобом, завдяки якому він матиме змогу детально вивчити відповідні явища та об'єкти за обраним напрямом, обґрунтувати актуальність результатів наукового пошуку та втілити їх у практичну діяльність для оптимізації професійної діяльності. О. Дубасенюк [1, с. 43], В. Зацерковний [2, с. 53], А. Пономарьов [3, с. 24], В. Юринець [4, с. 13] вбачають значущість методології у можливості логічної організації наукового дослідження, інорормування про методи, способи та форми наукового пошуку. Л. Калініна зазначає, що на сучасному етапі теорії наукового пізнання виділяють від двох до чотирьох рівнів методології, де методики відносять до останнього рівня як процедуру або алгоритм гносеологічних і трансформаційних операцій, націлених на розв'язання практичних завдань дослідження [5, с. 9].

Дворівнева методологія передбачає наявність теоретичного та емпіричного рівнів, що відповідають рівням наукового пізнання у теорії фрілософіії. В основі теоретичного рівня лежать фрілософські методи та принципи діалектики. До основних принципів діалектики відносять: принцип розвитку; принцип єдності історичного і логічного; принцип всезагального зв'язку і взаємозалежності предметів та явищ; принцип системності; принцип сходження від абстрактного до конкретного. Емпіричний рівень методології стосується вибору і дослідження емпіричного об'єкта, а також процесу обробки і систематизації отриманих фрактів про досліджуваний об'єкт. До першої групи методів емпіричного рівня відносимо такі практичні форми пізнання, як спостереження; опис; порівняння; вимірювання; експеримент; моделювання, що здійснюються шляхом абстрагування, фрормалізації чи ідеалізації, а також математичним моделюванням. Друга група представлена такими методами, як аналіз і синтез; індукція, дедукція; аналогія; абстрагування і конкретизація; систематизація та класифрікація та інші. Ці методи називають також загальнологічними методами пізнання [6, с. 179-182].
Прихильниками трирівневої системи методології $€$ С. Гончаренко, В. Маслов, Н. Шевандрін. Н. Шевандрін виділяє загальну методологію, спеціальну методологію та сукупність конкретних методів, методик і процедур [цит. за 1, с. 42], тоді як В. Маслов називає такі рівні фрілософським, теоретичним та технологічним (методичним), тобто діяльнісним [7, с. 112]. С. Гончаренко виділяє загальнофрілософрську, загальну та часткову методологію [8, с. 207].

Досить поширеною в сучасній науково-педагогічній літературі $€$ чотирирівнева структура методології наукового дослідження. Так, Е. Юдін вищим або першим рівнем вважає фрілософську методологію, яка використовує загальнофрілософські методи пізнання та категорії, другий рівень загальнонауковий, що стосується вивчення сукупності наукових дисциплін, третій рівень науковець означує як конкретно-наукову методологію, визначаючи сферу її застосування в спеціальній науковій дисципліні. Четвертий рівень науковець означує як технологічну методологію, основу якої становлять методики і техніка дослідження, тобто набір процедур, які забезпечують отримання достовірного емпіричного матеріалу і його первинну обробку [1, с. 41]. А. Єрьомін рівні методології поділяє на фрілософрський, загальнонауковий, конкретно-науковий та міждисциплінарний. Для кожного з рівнів притаманні методи пізнання, а саме: для фрілософрського це метод сходження від абстрактного до конкретного, діалектичні та метафрізичні методи, метод переходу від історичного в логічне. Другий рівень передбачає застосування загальнонаукових та логічних методів. Конкретнонауковий рівень методології послуговується методами емпіричного і теоретичного дослідження. Міждисциплінарний рівень слугує для індукування результатів наукового дослідження, розширюючи сореру їх застосування від однієї навчальної дисципліни до низки споріднених [10, с. 41].

Виділення не вирішених раніше частин загальної проблеми. На етапі сучасних інтеграційних процесів до європейського освітнього простору та стандартів НАТО майбутній військовослужбовець, маючи статус курсанта, повинен відповідати сучасним вимогам кваліфрікованого фрахівця, володіючи набором компетентностей, що отримуються під час навчального процесу. На нашу думку, особливо важливого значення нині набуває міжкультурна компетентність як особистісне утворення, що $€$ засобом профресійної соціалізації у процесі комунікативної взаємодії 3 представниками інших національностей для вирішення службових завдань. Вищезазначена компетентність формується у курсантів вищих військових навчальних закладів передусім у процесі засвоєння навчальних дисциплін гуманітарного циклу, таких як культурологія, українська та 
іноземні мови, релігієзнавство, політологія тощо. Зважаючи на те, що англійська мова $€$ засобом міжнаціонального спілкування, саме під час іншомовної підготовки відбувається залучення курсантів до культурних цінностей та традицій інших націй завдяки вивченню мови, відбувається нівелювання мовного бар'єру та виховується інтернаціональна толерантність. Як відомо, рівень сорормованості будь-яких компетентностей залежить від багатьох чинників. По перше, це результат підготовки як викладача, тобто методологічна база та вдало обрана стратегія викладання, так і курсанта - його когнітивно-гносеологічні здібності, а також вхідний, проміжний та підсумковий рівень сорормованості мовно-культурологічних компетенцій. Викладач має обрати відповідну стратегію, дотримуючись якої, можемо досягти визначених програмами результатів. Оскільки метою та завданнями дослідження $€$ фрормування міжкультурної компетентності, варто розглянути науково-педагогічні підходи та методи як засоби загальної стратегії навчання. Сучасні тенденції у розвитку методології та педагогіки вищої школи вказують на те, що немає єдиного «правильного» методу, оскільки кожен із зазначених має свої «за» і «проти». Відбувається процес пошуку оптимальних комбінацій відомих методів та підходів, зважаючи на мету, сутність, часові та вікові обмеження, а також на особливості аудиторії, на яку спрямований педагогічний вплив.

Формулювання цілей статті. Мета статті полягає в обґрунтуванні основних положень та доцільності застосування традиційних та сучасних методів навчання та науково-педагогічних підходів, як загальнонаукових, так і конкретно-наукових, на основі аналізу їх особливостей для фрормування міжкультурної компетентності курсантів вищих військових навчальних закладів.

Виклад основного матеріалу дослідження. Розвиток наукових підходів, методів і технологій навчання почався ще за часів процвітання культури Стародавньої Греції та Риму. Для педагогів того часу важливо було навчити не лише застосовувати набуті знання з класичних мов, а й аналізувати їх. Наприкінці 19-го століття з розвитком торговельних зв'язків між державами збільшився діапазон мов, які потрібно було розуміти для вирішення ділових питань. На той час актуальності набуває натуральний підхід до вивчення іноземних мов. За таким підходом учні мали вивчати іноземні мови як першу мову, яку вчить дитина, тобто шляхом імітації мовленнєвих патернів іншої мови, багаторазового повторення і механічного заучування. Хоча такий підхід призначений для тривалого курсу вивчення мови, все ж головна мета навчання за натурального методу схожа з цілями сучасних комунікативних підходів - навчити учнів розмовляти іноземною мовою. За осно- воположними принципами цього методу передбачалося, що, навчившись говорити іноземною мовою, учні можуть читати і писати природним шляхом. 3 погляду військової освіти такий метод може застосовуватися за умов диференційованого навчання у групах, де курсанти мають різний рівень володіння іноземною мовою: дуже часто доводиться навчати тих, хто вивчав іншу іноземну мову, але навчальний час, зміст навчальної дисципліни і критерії оцінювання залишаються однаковими для усього загалу тих, хто навчається. У такому разі відбувається «занурення» курсантів у іншомовну атмосферу, де одні курсанти удосконалюють свої компетенції висловлюючи власні думки, інші - починають опановувати мову шляхом залучення до діалогу.

До початку 20 століття актуальними були такі підходи, як граматично-перекладний та прямий. Зважаючи на те, що одним із способів оволодіння іноземною мовою було вивчення текстів мови, яка вивчається, увагу педагогів привертали сталі вирази та граматичні конструкції, що періодично повторюються. Така ідея і стала основоположною у граматично-перекладному підході, де основною метою є володіння граматикою і словником. Таким чином, курс вивчення мови представлений вибіркою текстів для вивчення тієї чи іншої граматичної схеми. Недоліками такого підходу є те, що не враховується зміст і складність текстів; мова, що вивчається, використовується недостатньо, адже пояснення здійснюється рідною мовою; одноманітність завдань, які полягають у перекладі текстів; комунікація не є ціллю такого підходу [11]. Для військовослужбовця, який бере участь у міжнародних навчаннях та спільних військових операціях, важливим є зрозуміти інорормацію і бути здатним відреагувати на неї, тому словниковий запас у такому разі має вирішальне значення. Таким чином, цей підхід може бути застосований частково для висвітлення таких питань граматичного матеріалу, нерозуміння яких може призводити до спотворення або неправильної інтерпретації змісту.

У кінці 18-го століття з'являється текстуальноперекладний метод. Такий метод можна розглядати як варіацію граматично-перекладного, оскільки за основу навчального матеріалу, що вивчався, бралися також тексти, але зразками слугували оригінальні твори художньої літератури, на прикладі яких відпрацьовувалася фронетика, граматика та лексика. Вагомою перевагою під час такого навчання вважається застосовування зворотних перекладів та аналітичного читання, до чого викладач вищого військового закладу освіти часто вдається під час вивчення тем із спеціальною термінологією, наприклад для загальновійськового та військово-спеціального курсів вивчення іноземної мови. 
Наприкінці 19-го століття 3'являється суттєво відмінний від попереднього прямий метод вивчення іноземних мов. Суть методу полягає у тому, що навчання здійснюється лише засобами мови, що вивчається, граматика розглядається вибірково, навчальний процес зорієнтований на спілкування. Попри комунікативну направленість і здатність подолання мовного бар'єру, цей метод має низку недоліків: абсолютне усунення рідної мови з процесу вивчення іноземних мов може стати перешкодою для з'ясування складних завдань чи з'ясування значень абстрактних понять або термінів; суттєва відмінність моделей побудови лексико-граматичних парадигм рідної та іноземної мови може вимагати додаткових роз'яснень рідною мовою; збільшення часу на розвиток усного мовлення призведе до неможливості належним чином розвивати інші види мовленнєвої діяльності; перебільшення ролі індукції як єдиного способу засвоєння граматичних правил також розцінюється як недолік цього методу [12].

У 20-му столітті набули розвитку такі підходи й методи, як аудіолінгвальний та аудіовізуальний, усний підхід (ситуативне вивчення), комунікативний підхід, метод мовчання, метод занурення, метод повного фрізичного реагування, метод «громади» (метод «радника») тощо.

Аудіолінгвальний підхід виник під час Другої світової війни для швидкого оволодіння солдатами іноземними мовами як поєднання прямого методу, структурної лінгвістики та біхевіоризму. Велика роль у доборі навчального матеріалу належить діалогам, з яких розпочинається заняття; граматика подається індуктивним способом; розвиток видів мовленнєвої діяльності відбувається у чіткій послідовності: спочатку аудіювання і мовлення, після цього - читання й письмо. Такий підхід часто знаходить застосування у сучасній практиці викладання іноземних мов, оскільки має на меті розвиток усіх видів мовленнєвої діяльності.

Ґрунтуючись на засадах прямого та аудіолінгвального методів, у США і Франції започатковується аудіовізуальний метод. Основні принципи його розробники Р. Губернія, П. Ріван, Ж. Гугенейм і Р. Мішеа сорормулювали таким чином: весь мовний матеріал сприймається тривалий час тільки на слух, а семантизується майже виключно на основі зорової наочності за допомогою сучасної техніки [13, с. 82].

Усний метод був розроблений у середині 20-го століття британськими лінгвістами Гарольдом Палмером та А.С. Горнсбі. Заснований на прямих методах, усний підхід до вивчення іноземних мов був націлений на розвиток усіх видів мовленнєвої діяльності. Вагомою перевагою такого методу стали принципи змістовності, системності й послідовності у викладі навчального матеріалу [14]. Те, що лексико-граматичний матеріал представлений у «ситуаціях», давало змогу учням послідовно і свідомо вивчати мову. Цей метод викладання базувався на так званому принципі ППП: презентація (введення нового матеріалу в контексті), практика (контрольована практична фраза) і продукція (розвиток продуктивних вмінь та навичок). Саме цей метод став базовим принципом для створення комунікативного підходу [15]. Комунікативний підхід нині широко застосовується у викладанні іноземних мов і допомагає втілювати сучасні тенденції освітнього процесу у вищій освіті. Дослідник $€$. Пассов зазначає, що організація навчального процесу повинна імітувати процес спілкування, під час якого учні як учасники соціальної взаємодії вирішують ситуативні завдання [16, с. 36]. Провідними результатами навчання іноземних мов в освітніх програмах вищих військових закладів є вміння розмовляти, спілкуватися, вести діалог. Саме такі компетенції дозволяє розвивати усний метод та комунікативний підхід.

Основною характеристикою методу мовчання $€$ зведення до мінімуму мовлення вчителя з метою активізації мовленнєвих вмінь і навичок учнів. Навчаючи на молодших рівнях вимові, вчитель користується складними кольоровими таблицями, на яких кожен колір або символ позначає певний звук, таким чином презентуючи нові слова. На нашу думку, такий метод може застосовуватися на початковому етапі вивчення мови і лише як елемент заняття для введення лексичного матеріалу, оскільки може сповільнювати темп заняття і вимагатиме від викладача значних витрат часу на підготовку.

Метод занурення або сугестопедичний метод був представлений Ґ. Лозановим у другій половині 20-гго століття. Такий метод застосовується як для інтенсивного, так і для тривалого навчання. Основна мета - подолання психологічних бар'єрів за допомогою розширених прихованих можливостей людини із засвоєнням максимального обсягу матеріалу завдяки невимушеному спілкуванню учасників мовленнєвої взаємодії у зручному оточенні, часто з музичним супроводом. Р. Грановська під «зануренням» розуміє активний метод навчання з елементами релаксації, навіювання та гри, а поняття «занурення» і «сугестопедія» дослідниця ототожнює. Результатом навіювання є незвичайно висока концентрація уваги, розкріпачення творчих здібностей. «Метод занурення спирається на три принципи: задоволення і релаксацію, єдність свідомого і підсвідомого, двосторонній зв'язок» $[17$, с. 492]. Вибіркове застосування такого методу під час іншомовної підготовки курсантів може стати умовою подолання мовних бар'єрів та розвитку стійкого морально-психологічного клімату серед учасників спілкування.

Метод повного фрізичного реагування здійснюється через моторну активність за схемою: 
вчитель дає команду, учень виконує дію. На наш погляд, такий метод може розглядатися здебільшого як елемент заняття через ряд особливостей: неможливість розвитку компетенцій спонтанного мовлення; штучність ситуацій, які відтворюються; однотипність завдань; розвиток навичок лише одного виду мовленнєвої діяльності.

Метод «громади», метод «радника» або соціалізованого навчання (Community Language Learning - CLL) був запропонований американським психологом Ч. Курраном як реакція на гуманістичний підхід у навчанні. Під час занять застосовується як рідна, так і мова, що вивчається. Учні зазвичай у колі обговорюють питання, далі - аналізують лексико-граматичне наповнення навчального матеріалу. Вчитель виступає у ролі «радника», який ненав'язливо пропонує варіанти відповідей чи перекладу фраз, якими учні послуговуються під час бесіди. Е. Соловова зазначає, що даний метод не набув значного поширення через відсутність програм і планів, конкретних цілей і завдань курсу навчання. [18, с. 118]. У системі ж військової освіти такий метод можливо використати у позааудиторний час: під час фракультативів та мовних гуртків як альтернативну фрорму проведення навчально-освітніх заходів.

3 огляду на різноманітність методів та підходів до вивчення іноземної мови як засобу фрормування міжкультурної компетентності, варто зазначити, що викладач, добираючи дієві методики і технології, послуговується тими чи іншими або їх комбінаціями, на що впливає як підготовленість та особливість аудиторії, так і цілі навчання. Нині процеси імерсії та пенетрації методів та підходів відомі як еклектичний підхід у навчанні, що дозволяє як викладачу, та і курсантам проявляти гнучкість у взаємодії під час навчання.

Висновки і подальші перспективи в цьому напрямі. Отже, нами зроблено спробу проаналізувати методи та підходи, що застосовуються у педагогічній практиці загалом та під час іншомовної підготовки зокрема, а також розглянути їх характерні риси. У процесі аналітичних зіставлень з'ясовано переваги та недоліки кожного із методів та підходів й умови, за яких доцільне застосування кожного 3 них для фрормування міжкультурної компетентності курсантів вищих військових навчальних закладів.

Оскільки іноземна мова є невід'ємним компонентом освітньої програми підготовки військового спеціаліста, важливою умовою фрормування кваліфрікованого та підготовленого фрахівця $є$ набуття ним низки загальних компетентностей, серед яких - здатність розв'язувати складні спеціалізовані завдання у практичних ситуаціях та здатність професійно спілкуватися іноземною мовою як усно, так і письмово. Для досягнення таких цілей викладач повинен комплексно підходити до організації навчального процесу, володіючи арсеналом методів та підходів, застосування або комбінування яких стане запорукою оптимізації процесу набуття курсантами потрібних компетенцій та компетентностей.

\section{БІБЛІОГРАФІЧНИЙ СПИСОК:}

1. Дубасенюк О.А. Методологія та методи науково-педагогічного дослідження : навч.-метод. посіб. Житомир : Полісся, 2018. 256 с.

2. Зацерковний В.І., Тішаєв І.В., Демидов В.К. Методологія наукових досліджень : навч. посіб. Ніжин : НДУ ім. М. Гоголя, 2017. 236 с.

3. Пономарев А.Б., Пикулева Э.А. Методология научных исследований : учеб. пособ. Пермь : Изд-во Перм. нац. исслед. политехн. ун-та, 2014. 186 с.

4. Юринець В.Є. Методологія наукових досліджень : навч. посіб. Львів : ЛНУ імені Івана Франка, 2011. 178 c.

5. Калініна Л.В. Науковий дискурс сучасних методологій організаційного механізму управління в сфрері освіти. Рідна школа. Теорія й методологія освіти. 2017. № 1-2 (січень-лютий). С. 8-17.

6. Щерба С.П., Щедрін В. К., Заглада О.А. Філософрія : навч. посіб. Київ : МАУП, 2004. 216 с.

7. Маслов В.І., Ситар І.В. Головні структурні складові наукових досліджень педагогічних систем. Вісник післядипломної освіти. 2015. Вип. 15. С. 108-122. URL: http://nbuv.gov.ua/UJRN/Npo_2015_15_12 (дата звернення: 14.03.2021).

8. Гончаренко С. У. Український педагогічний словник. Київ : Либідь, 1997. 366 с.

9. Методология науки : учебно-методическое пособие для аспирантов и соискателей : в 3 т. / глав. ред. А. Д. Ерёмин. Саров : СарФТИ, 2019. Т. 1. Методология и организация научного исследования. 67 с.

10. Kelly L. G. Twenty-five centuries of language teaching. Rowley, MA : Newbury House Publ., 1976. $474 \mathrm{p}$.

11. Бистрова Б.В. Переваги застосування прямого методу викладання іноземних мов у процесі її вивчення. Гуманітарна освіта у технічних вищих навчальних закладах. 2009. Вип. 17. С. 207-213. URL: $\quad$ http://jrnl.nau.edu.ua/index.php/go/issue/view/99 (дата звернення: 10.03.2021).

12. Нікіфорова С.М., Пивоварова Н.І., Пивоварова О.І. Еволюція методів навчання іноземної мови. Теорія та методика навчання та виховання. 2019. № 46. C. 70-91.

13. Howatt A.P. R., Widdowson H.G. A history of English language teaching ( $2^{\text {nd }}$ ed.). Oxford, UK : Oxford University Press. 2004. 417 p.

14. Richards Jack C., Theodore S. Rodgers. Approaches and Methods in Language Teaching. Cambridge, UK : Cambridge University Press. 2001. $169 \mathrm{p}$.

15. Пассов Е.И. Коммуникативный метод обучения иноязычной речи. Москва : Просвещение, 2004. $324 \mathrm{c}$.

16. Грановская Р.М. Элементы практической психологии. Изд. 2-е. Ленинград, 1988. 560 с.

17. Соловова Е.Н. Методика обучения иностранным языкам: базовый курс лекций : пособие для студентов пед. вузов и учителей. Москва : Просвещение, 2002. 239 с. 